\begin{tabular}{|l|l|l||}
\hline \multicolumn{2}{|c|}{ PublisherInfo } \\
\hline \hline PublisherName & $:$ & BioMed Central \\
\hline \hline PublisherLocation & $:$ & London \\
\hline \hline PublisherImprintName & $:$ & BioMed Central \\
\hline \hline
\end{tabular}

\title{
Microsatellites in plant genomes
}

\begin{tabular}{|l|l|l||}
\hline \multicolumn{2}{|c|}{ ArticleInfo } \\
\hline \hline ArticleID & $:$ & 4386 \\
\hline \hline ArticleDOI & $:$ & $10.1186 /$ gb-spotlight-20020128-01 \\
\hline \hline ArticleCitationID & $:$ & spotlight-20020128-01 \\
\hline \hline ArticleSequenceNumber & $:$ & 52 \\
\hline \hline ArticleCategory & $:$ & Research news \\
\hline ArticleFirstPage & $:$ & 1 \\
\hline \hline ArticleLastPage & $:$ & 2 \\
\hline \hline & & RegistrationDate : 2002-1-28 \\
\hline ArticleHistory & $:$ & OnlineDate \\
\hline \hline ArticleCopyright & $:$ & BioMed Central Ltd2002-1-28 \\
\hline \hline ArticleGrants & $:$ & \\
\hline \hline ArticleContext & $:$ & 130593311 \\
\hline \hline
\end{tabular}




\section{Jonathan B Weitzman}

Email: jonathanweitzman@hotmail.com

Microsatellites are simple repetitive DNA sequences scattered throughout eukaryote genomes. In an Advanced Online Publication from Nature Genetics, Morgante et al. report their analysis of the density and distribution of microsatellites in several plant genomes (22 January 2002, DOI:10.1038/ng822). They compared the genomes of Arabidopsis thaliana, rice (Oryza sativa) soybean (Glycine max) maize (Zea mays) and wheat (Triticum aestivum), whose haploid genomes vary 50-fold in size. They found an enrichment of microsatellites in transcribed regions, particularly in untranslated regions. They also found that microsatellite frequency is not a function of overall genome size. Microsatellites were more frequent in single- or low-copy DNA fractions than in repetitive DNA. These results suggest that microsatellites do not originate from repetitive DNA, as was previously proposed.

\section{References}

1. Microsatellites in different eukaryotic genomes: survey and analysis.

2. Nature Genetics, [http://www.nature.com/ng/] 